\title{
塗り床のふくれ発生に及ぼす下地コンクリートの影響 \\ EFFECT OF PROPERTY OF SUBSTRATE CONCRETE ON BLISTERING OF EPOXY RESIN FLOOR COATINGS
}

\author{
田中享二*1, 内田昌宏*2, 大森 修*3, 裴 基 善*4 \\ Kyoji TANAKA, Masahiro UCHIDA, Osamu OHMORI \\ and Keesun BAE
}

\begin{abstract}
Effect of property of substrate concrete on blistering of floor coatings is studied from the two view points such as property of concrete itself and surface characteristics. The concrete specimens of various water cement ratios, on which floor coatings is applied, were exposed in the accelerated condition for reproducing blistering, and growth of blisters were observed for a few months. After the test, adhesive strength was measured and the concrete surface was observed through a microscope. It was found out that blistering is much influenced by the water flux property induced by semi-permeability of concrete, and the distribution of adhesive strength caused by exposed materials on surface such as cement paste, aggregates and laitance.
\end{abstract}

\section{Kerwords:blistering, epoxy resin, floor coatings, concrete substrate, surface, adhesive strength \\ ふくれ, エポキシ樹脂, 塗床, コンクリート下地, 表面, 接着力}

\section{1. はじめに}

コンクリートを下地とする塗床にはふくれが発生することがある が、その主たる発生機構はコンクリートを介しての水分の一方向移 動による塗床材裏面での集積と、そのことによる圧力上昇であるこ とを、前報"では明かにした。この現象にはコンクリートの性質が 強く関与していることは明かであり、この欠陥を未然に防止するた めには、下地コンクリートのふくれ発生に及ぼす影響を知ることが 不可欠である。

下地コンクリートの影響は二つの観点から検討する必要があると 思われる。ひとつは、ふくれを発生させる駆動力にどのような影響 をもつかという点である。すでに述べたように、ふくれの駆動力は 水分の一方向移動に起因する浸透圧と考えられ、コンクリートによ ってその大きさは異なると想像されるからである。

いまひとつは、下地コンクリートの塗床材の接着力に及ぼす影響 である。実際の塗床に生ずるふくれは、ただひとつだけが発生する ということはまれで、ほとんどの場合、直径が数十ミリメートル以 下のものが数多く発生する。この現象はふくれに伴う水分の蓄積が、 塗床材と下地コンクリート表面との間であったことから判断して、 ふくれ現象は両者間での接着部の破壊として理解されるが、コンク
リート表面はミクロ的には均質ではないため、接着力が均一である とは考えにくい。さらに一般に水分の多い環境下では、接着力が低 下寸る傾向にあることを考慮すると、下地コンクリートの表面性状 の接着力に及ぼす影響の解明もまた重要である。

このような観点から、本研究では下地のコンクリートに焦点をあ わせ、コンクリート自身およびその表面の性質がふくれ発生に及ぼ

す影響について検討した。

なお既往の研究についてであるが、床材のふくれに関しては以前 から強い関心がもたれ、下地コンクリートの半透過性的性質がその 原因のひとつであるとの立場から、W. J. Warlow等 ${ }^{21}$ 、M. Gunter等 ${ }^{3)}$ 、 中井等" により研究がなされている。しかしいずれの研究も原因指 摘の段階に留まっており、下地コンクリートのおよぼす影響につい て検討されるまでには至っていない。

また塗床材料と下地コンクリートとの接着力については、古くは 前述のM. Gunter等 ${ }^{3)}$ 、喜田等 ${ }^{5)}$ の直接引張試験による検討、最近で は、逸見等 ${ }^{6)}$ の皮はぎ式剥離接着強さ試験法、守屋等 ${ }^{7)}$ のベルジャ 一をかぶせての減圧試験法などニニークな試験法の提案がなされて いる。しかし、接着力の細かな分布を調べる目的には、これらの試 験法では測定部分のサイズが大きすぎるように思える。この観点か

\footnotetext{
*1 東京工業大学建築物理研究センター 助教授 $\cdot$ 工博

*2 エービーシ一商会研究所

*3 旭化成建材 (元東京工業大学 大学院生) 工修

${ }^{* 4}$ 東京工業大学 大学院生・工修
}

Assoc. Prof., Structural Engineering Research Center, Tokyo Institute of Technology, Dr. Eng.

Research Laboratory, ABC Trading, Co., Ltd.

Asahi Chemical Construction Materials Co., Ltd., M. Eng. Graduate Student, Tokyo Institute of Technology, M. Eng. 
らの塗床の接着力分布はほとんど検討されていないのが害状である。

2 ふくれ促進試験

2. 1 下地コンクリート

下地コンクリートは、水セメント比 $45 \% 、 60 \% 、 75 \%$ の 3 種類のコンクリートである。調合を表 1 に示す。目標のスランプ值 $18 \mathrm{~cm}$ とするため A E 減水剤の添加量を変えたが、出来上がったコ ンクリートはスランプ値 $20 \sim 21 \mathrm{~cm} の$ 多少軟らかめのものとなっ た。寸法は直径 $490 \mathrm{~mm}$ 、厚さ $120 \mathrm{~mm}$ の円盤状の下地とした。 使用した骨材の性状を表一 2 に示す。コンクリート打ち込み後 28 日間、 $20{ }^{\circ} \mathrm{C}$ 恒温室で気中養生を行った。またその表面はサンドぺ 一パー（№.1 800$)$ で研磨し、充分清掃した状態とした。

\section{2 ふくれ観察用試験体}

上述の下地コンクリートにエポキシ樹脂系塗床材を塗布した。こ こで用いた塗床材は、図 1 に力学的特性を示す軟質塗材、硬質塗材、 各 $1 \mathrm{~mm}$ 号つの 2 層構成のもので、ふくれ発生を容易にするため、 通常の硬質塗材の下側に軟質塗材料を積層したものである。試験体 作製手順を図 2 に示すが、試験体完成までに下地コンクリート打ち 込みから 6 週間要する。

\section{3 ふくれ圧力測定用試験体}

ふくれ圧力の測定では、ふくれの発生する位置に圧力測定器を設 置することが大切である。しかしその位置を予測することは現状で は難しい。そのため、圧力測定用試験体では、軟質塗材を塗布した 段階で後述のふくれ促進環境に試験体を設置し、小さなふくれが発 生した時点で、その位置に圧力測定器（共和電業社製PGM-10KE）を 取り付けた。ふくれ発生までの時間は水セメント比により異なるた め、その取り付け時期が異なり、結果的には水セメント比 $75 \%$ の 場合が一番早く試験開始 7 日後、60\%の場合が 28 日後、 $45 \%$ の場合が 160 日後であった。

圧力測定器の取り付け方法は、ふくれ部分の塗材を直径 $10 \mathrm{~mm} ゙ く$ り抜き、下地コンクリート表面を露出させ、図 3 に示すように下側 の軟質塗材に測定器の端部を乗せ、その後硬質塗材を $1 \mathrm{~mm}$ 塗布し た。圧力測定部分の空間は約 $0.13 \mathrm{CC} の$ 容積となる。さらに試験時の 取扱上の安全のため、圧力測定器のまわりをエポキシパテにより補 強した。

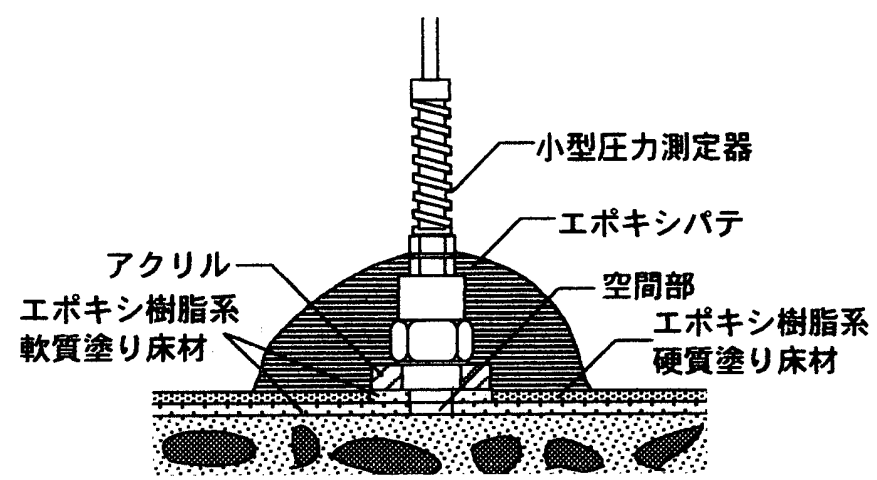

図一 3 圧力測定器取り付け状態
表ー1 下地コンクリートの調合

\begin{tabular}{|c|c|c|c|c|c|c|c|c|}
\hline \multirow{2}{*}{$\begin{array}{l}W / C \\
(\%)\end{array}$} & \multirow{2}{*}{$\begin{array}{c}\text { 細骨材率 } \\
(\%)\end{array}$} & \multicolumn{4}{|c|}{ 貍位重量 $\left(\mathrm{kg} / \mathrm{m}^{3}\right)$} & \multirow{2}{*}{$\begin{array}{r}A E \text { 減水剂 } \\
\left(\mathrm{kg} / \mathrm{m}^{3}\right)\end{array}$} & \multirow{2}{*}{$\begin{array}{l}\text { スランプ } \\
(\mathrm{cm})\end{array}$} & \multirow{2}{*}{$\begin{array}{c}\text { 空気 } \\
(\%)\end{array}$} \\
\hline & & 水 & セxント & 細骨材 & 粗骨材 & & & \\
\hline 45 & 41.5 & 185 & 414 & 692 & 988 & 1.04 & 20.0 & 3.0 \\
\hline 60 & 46.1 & 172 & 172 & 829 & 988 & 0.72 & 20.9 & 4. 0 \\
\hline 75 & 48.5 & 165 & 165 & 915 & 988 & 0.55 & 21.2 & 5.0 \\
\hline
\end{tabular}

セメント:普通ポルトランドセメント

骨材：細骨材；静岡県沢岡産の大井川陸砂 粗骨材; 静岡県沢岡産の大井川陸砂利

$A E$ 減水剂：リグニンスルホン酸化合物系

表一2 骨材の性状

\begin{tabular}{|c|c|c|}
\hline & $\begin{array}{l}\text { 表乾比重 } \\
(\mathrm{g} / \mathrm{cc})\end{array}$ & $\begin{array}{c}\text { 吸水率 } \\
(\%)\end{array}$ \\
\hline 細骨材 & 2.60 & 1.30 \\
\hline 粗骨材 & 2.65 & 0.73 \\
\hline
\end{tabular}

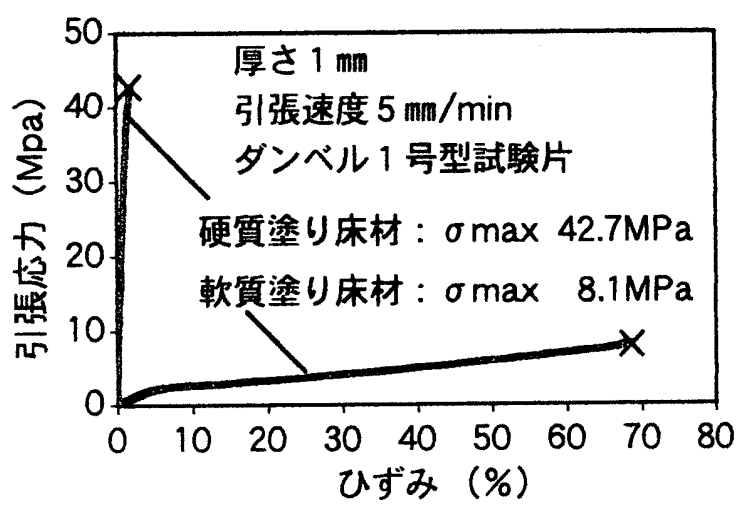

図ー1 澵り床材の応カーひずみ曲線

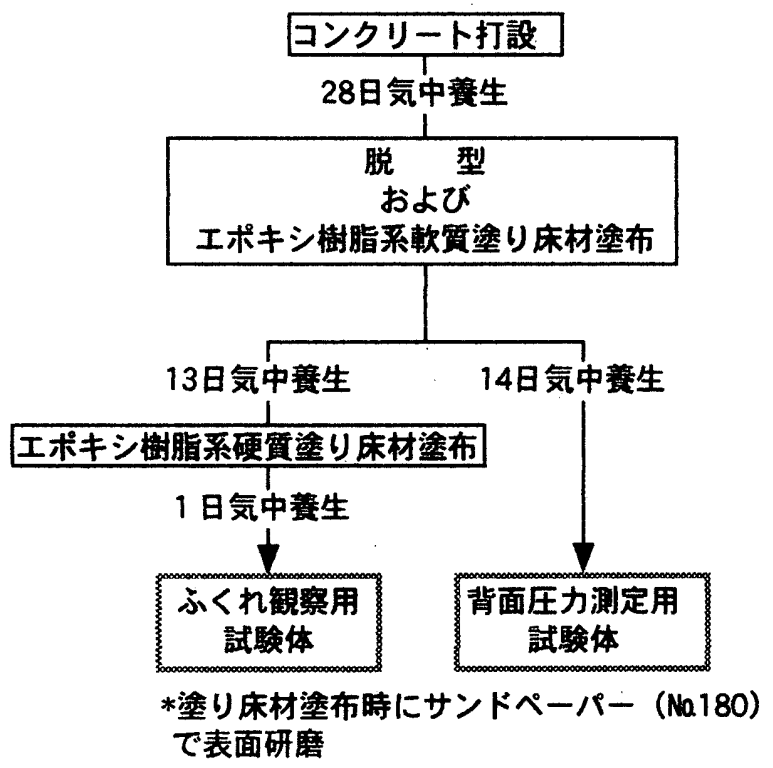

図－２試験体作製手順 


\section{4 試験方法}

各試験体は、前報告" で述べたふくれ促進環境、寸なわち図 4 に 示すように $30^{\circ} \mathrm{C}$ の温水を入れた容器にコンクリート表面から $10 \mathrm{~mm} の$ 位置まで浸漬させ、表面は $20{ }^{\circ} \mathrm{C}$ 温度下に露出させ、静置した。

ふくれ観察用試験体については、定期的に塗床材に発生するふく れを目視により観察し、ふくれの位置、大きさを記録した。一般に、 ふくれはまず試験体の外周に生じ、その後、全面にわたり発生する 傾向が見られる。すなわち外周近傍のふくれの発生は、試験体の外 側が直接水に接していることによるためであり、床として考えた時 の下側からの水の移動とはみなしにくい。そのため下地コンクリー 卜厚さと同じ寸法 $1.20 \mathrm{~mm}$ の外周範囲は、水に外接していること の影響と考え、観察範讲から除外し、ふくれ観察は中央部分直径 2 $50 \mathrm{~mm}$ の部分に限定した。

圧力測定用試験体については、一層目の軟質塗材を塗布後、同じ ように水に浸漬させ中央部直径 $250 \mathrm{~mm}$ 以内の部分でのふくれ発 生確認の後、ただちに前述の手順に従い圧力測定器を取り付け、そ の後の圧力変化を一日おきに測定した。な抢圧力測定器はふくれ 2 箇所に取り付けた。

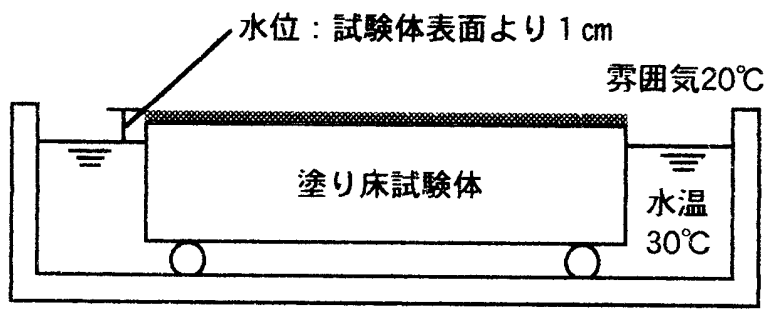

図-4 ふくれ促進試験状況

\section{5 試験結果および考察}

（1）ふくれの発生状況

試験体中央部直径 $250 \mathrm{~mm}$ の観察領域内のふくれ発生状況の観 察結果を図 5 に、またふくれの発生した面積を塗床材塗布面積の割 合で表し、図6に示す。下地コンクリートの水セメント比により明 瞭な差があり、ふくれが生じはじめたのは、水セメント比 $75 \%$ で 10日目、60\%で30日目、45\%で160日目であった。また その後のふくれの増加も水セメント比が大きな場合に顕著であり、 水セメント比 $75 \%$ では試験開始後 100 日程度、60\%では 15 0日程度であらかたのふくれは出てしまい、その後のふくれ成長は 緩慢となったのに対し、水セメント比 $45 \%$ の場合は 1 年間の観察 でも、塗床全面積の2 割程度しかふくれなかった。

\section{（2）ふくれ部およびその近傍の界面の顕微鏡観察}

塗床材と下地コンクリートの界面の状態を調べるために、塗床材 のふくれ部分とその近傍を下地コンクリート上り剥し取り、両面の 顕微鏡観察を行った。塗床材裏面を写真 1 に、下地コンクリート側 表面を写真 2 に示寸。

まず塗床材裏面であるが、ふくれ部分の面は比較的平滑であり、 下地と接着していた部分は無理に引き剥したためと思われるが、塗 床材もしくは下地コンクリート部分が破壊され、所凸状となってい る。またふくれの境界にそって亀裂がみられる。これはふくれ境界 部分での急激な曲げに対して、エポキシ塗床材の変形能力が十分で なかったためと推定される。

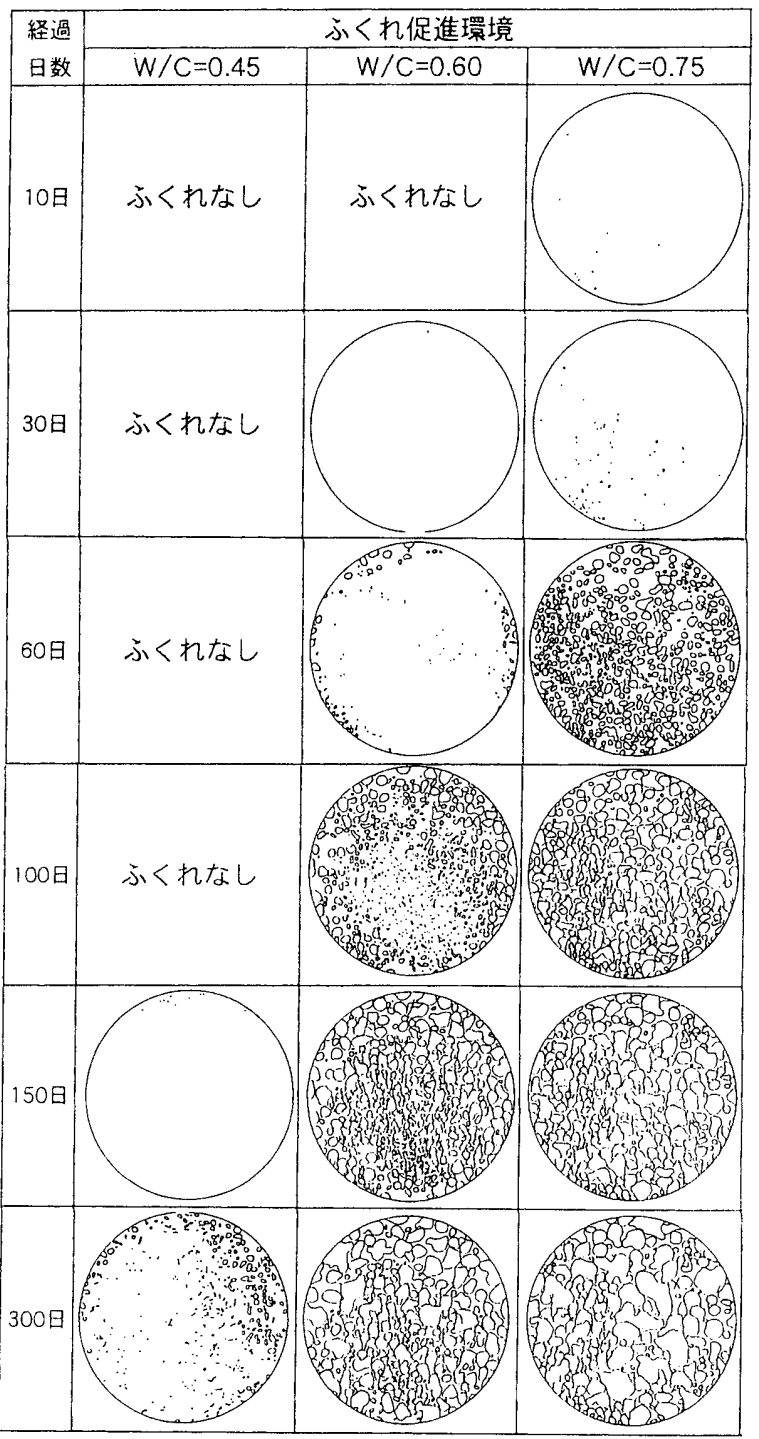

図－5 ふくれ発生状況の観察結果

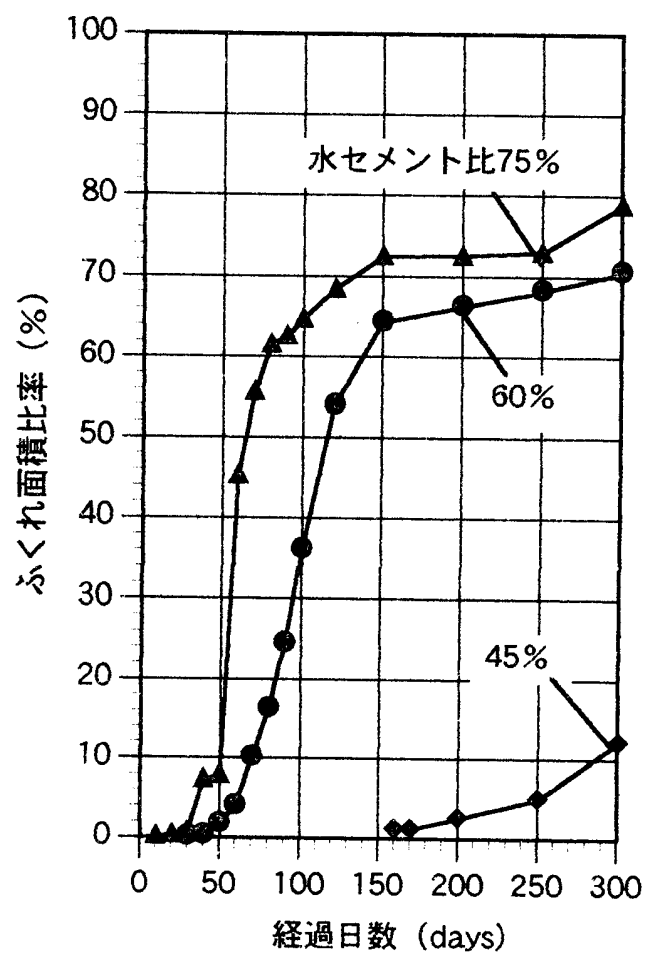

図-6 ふくれ発生面積比率の変化 
次に下地コンクリート側表面であるが、ふくれ発生部分は比較的 なめらかである。一方塗床材と良く接着していた部分は、やはり無 理に引き剥したため凹凸で塗床材が残されており、細骨材が見られ る。

塗床材塗布前に、前処理としてサンドペーパーで表面を研磨した が、細骨材が見られる部分は良く研磨された部分であり、なめらか な部分は、研磨されず、レイタンスがそのまま残留している部分に ほぼ対応している。

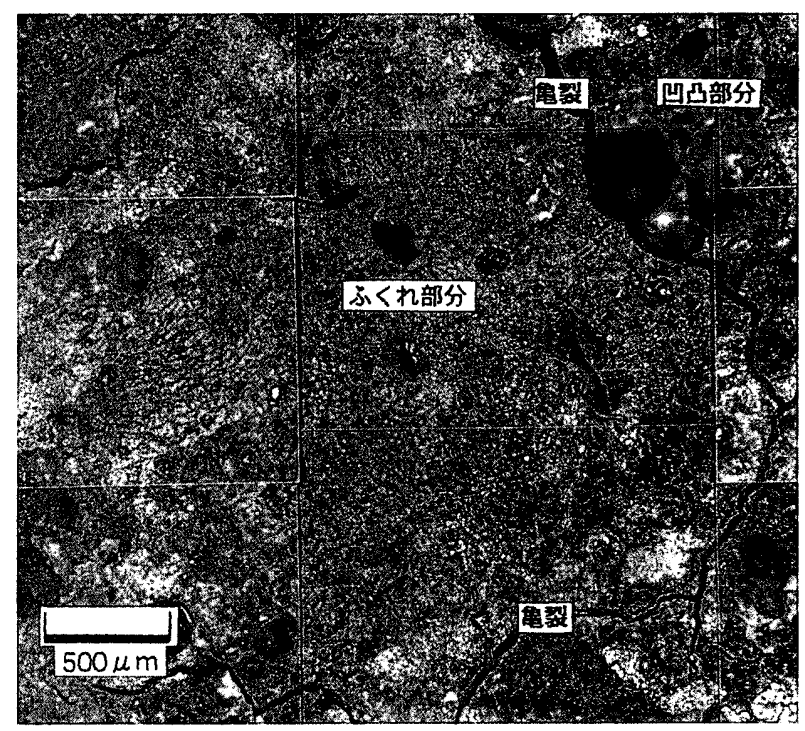

写真 -1 塗り床材裏面

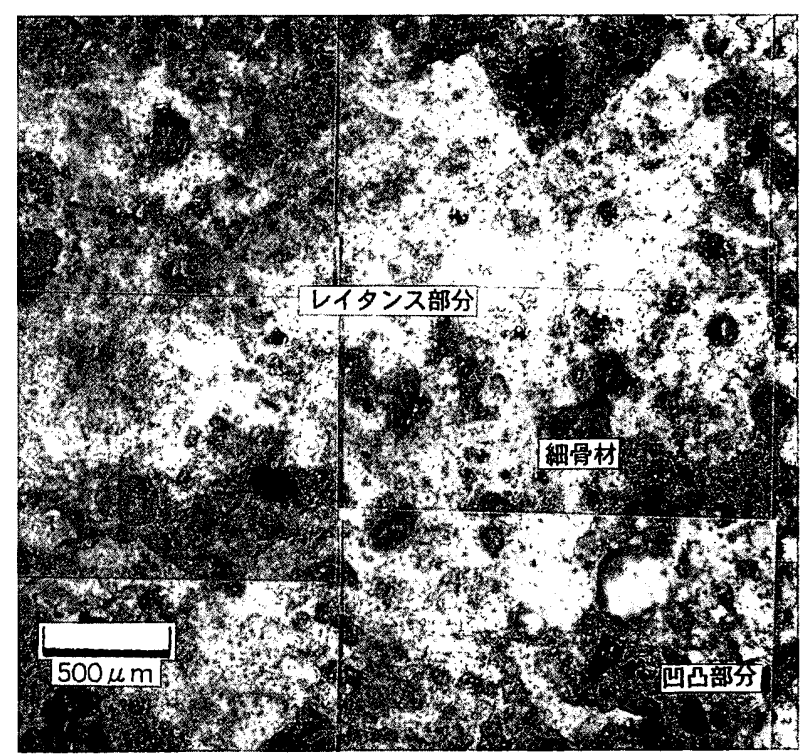

写真－2 下地コンクリート表面
(3) ふくれの圧力

ふくれ圧力の変化を図 7 に示す。圧力は単調に上昇するのではな く、上昇と下降を不規則に繰り返している。圧力が急激に低下して いるところは、ふくれ内部圧力の上昇により、塗床材が下地から剥 離し、ふくれ容積が変化したためと推定される。この場合も下地コ ンクリートの水セメント比の影響が顕著にみられており、水セメン 卜比の大きい下地コンクリートの場合に压力の発生が早く、また最 大となった時の圧力值も高い。ここでの測定では、水セメント比が $75 \%$ の試験体では、0.13MP a の正圧が観測されたが、60 $\%$ の場合では０．０ $3 \mathrm{MP}$ a、45\%の場合では、圧力測定器取り 付け後の日数が少ないせいもあるが、ごくわずかの正圧が生じてい るのみである。

（4）コンクリートの半透過性に起因寸る水の移動速度

これらふくれの発生が下地コンクリートの水セメント比によって 異なるのは、ふくれ内部が水溶液で満たされていることから判断し て、コンクリートの半透過性に起因する、ふくれ内部溶液側への水 の流入速度の差によると推定される。そのためこの水の移動速度测
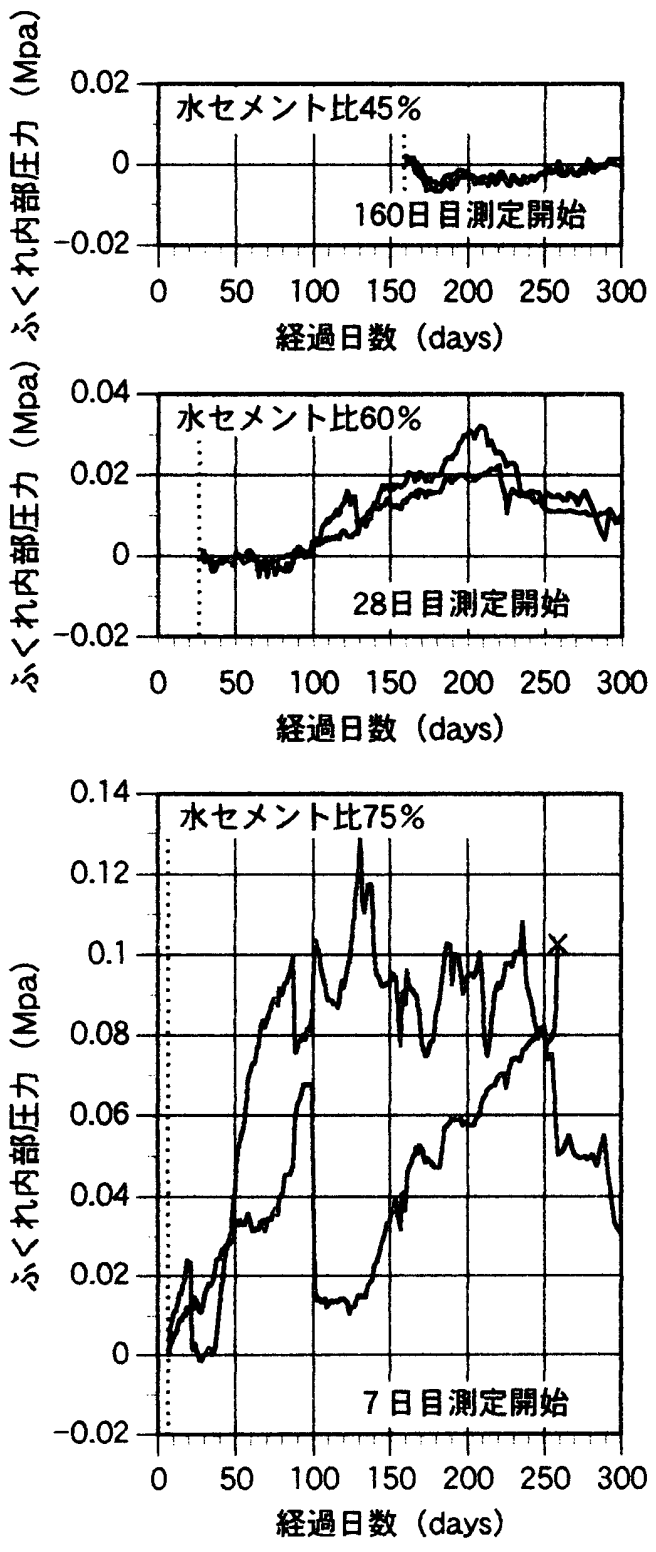

図一 7 ふくれ内部圧力测定結果 
定をおこなった。な拉、ふくれへの水移動の原因は、前報告"てでも 述べたが、塗床層裏面には結露等のため水分の生じることがあるが、 エポキシ樹脂系塗床材には水可溶性の有機成分が含まれ、この成分 が溶出し濃度を持った溶液となり、この溶液を薄めようとして、近 傍のコンクリート中の水分が移動するためと推定される。

試験体は水セメント比 $45 \%$ 、6 0 \% 、7 $5 \%$ とし、ふくれ試験 における下地コンクリートと同じ調合のものを、直径 $190 \mathrm{~mm} \phi$ 、 厚さ $120 \mathrm{~mm}$ の円筒状型枠に打ち込み、気乾状態で 3 ヶ月養生し たものである。これからさらに、100 $\mathrm{mm} \phi$ のコアを抜取り、そ の中央部分より厚さ $20 \mathrm{~mm}$ で切り出したものを試験体とした。こ の試験体を図 8 に示す浸透水量測定装置に取り付けた。I 側容器に はイオン交換した蒸留水を、II側容器にはエチルセロソルブ $5 \%$ 溶 液 (塗床ふくれ内部水として検出されたエポキシ塗床材可溶性成分 で測定された濃度）を入れ、30 $0^{\circ} \mathrm{C}$ 環境下に静置した。浸透量は、 2 日毎にガラス管の水頭差を0.5 mm単位で読み取った。試験体は 2 個である。

測定結果は 2 個の平均単位面積当りの移動水量として表し、図 9 に示す。コンクリート板を介して蒸留水側からエチルセロソルブ側 人、水がほぼ直線的に移動している。これをもとに大まかな水の移

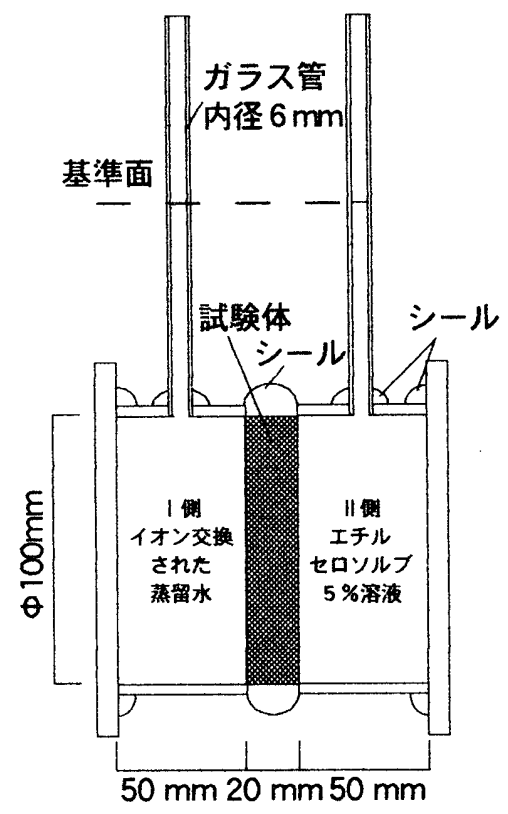

図-8 浸透水量測定装置

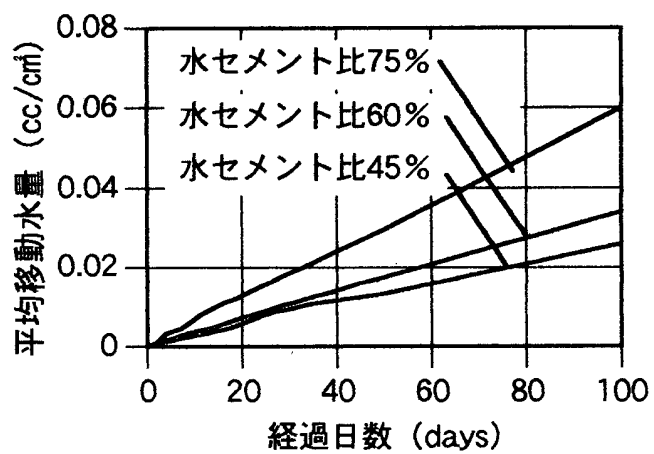

図ー9 単位面積当たりの移動水量
動速度を算出し、表 3 に示す。この場合も下地コンクリートの水セ メント比の影響が顕著であり、水セメント比が大きくなるに従って、 移動速度が大きくなっている。このことが、水セメント比の大きな 下地コンクリートに施工した塗床で、ふくれの発生が活発であった ことの理由であると推定される。

\section{3 塗床材と下地コンクリートの接着力}

ふくれ部分を解体し観察した結果から、塗床裏面では接着部分と 非接着部分が混在していることが明かになったが、このことは、エ ポキシ塗床材と下地コンクリートの接着力が均一ではないことに起 因していると思われる。このことの確認のため、接着力の分布を測 定した。

\section{1 試験体}

ふくれ促進試験と同様の水セメント比 $45 \%$ ，60\%，75\%の 3 種類の下地コンクリートを作り、養生後、表面を研磨、清掃し、 エポキシ系塗床材を塗布した。ただし、下地との接着力の測定の目 的には、上塗の硬質塗材は不要であり、下塗軟質塗材 $1 \mathrm{~mm}$ のみの 構成とした。塗床材を 7 日間養生したのち、表層部を直径 $30 \mathrm{~mm}$ 、 厚さ $5 \mathrm{~mm}$ の大きさに切り出し、試験体とした。その後、これら試 験体を $20{ }^{\circ} \mathrm{C} の$ 気乾状態に保管したが、実際のふくれ箇所には水分 が充満されていることを考慮し、別途、全体を水中に浸漬させ、充 分吸水させた試験体も用意した。

3. 2 测定方法

ふくれは、最初は数mm程度の微小なものが発生することから、通 常採用されるような数センチ以上のスケールの接着力試験では、小 さい面積間の接着力の不均一性を的確に評価することは難しいと思 われる。そのため、ここでは図 10 に示す小面積接着力試験方法を 工夫した。まずエポキシ塗床材にカッターナイフで $2 \mathrm{~mm} \times 2 \mathrm{~mm}$ の格 子状の切込みを下地コンクリートに到達するまで入れる。次いで塗 床材表面に、補強材としての金属線を内蔵するプラスチック紐を、 エポキシ樹脂系高速硬化型接着剤で接着させる。これを引張試験機

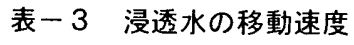

\begin{tabular}{|c|c|}
\hline $\begin{array}{c}\mathrm{W} / \mathrm{C} \\
(\%)\end{array}$ & $\begin{array}{c}\text { 移動速度 } \\
\left(\mathrm{cc} / \mathrm{cm}^{2} \cdot \mathrm{se} \mathrm{C}\right)\end{array}$ \\
\hline 45 & $3 \times 10^{-9}$ \\
\hline 60 & $4 \times 10^{-9}$ \\
\hline 75 & $6 \times 10^{-9}$ \\
\hline
\end{tabular}

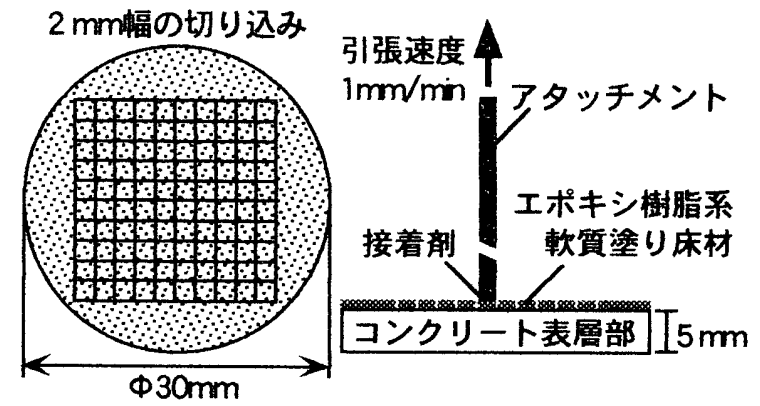

図－10 小面積接着力試験方法 
に取り付け、 $20{ }^{\circ} \mathrm{C}$ 環境下で $1 \mathrm{~mm} /$ 分の速度で引張り、接着力を 測定した。あわせて破断面の状態も観察した。

\section{3 試験結果および考察}

(1) 接着力分布

一例として、下地コンクリートの水セメント比 $60 \%$ の場合の接 着力分布を、気乾状態試験体、水中浸漬後試験体について図 11 に 示す。接着力は、気乾状態試験体で最大 $4.6 \mathrm{MP}$ a 、最少0.7M P a であり、6．5 倍程度の違い、水中浸漬後試験体では最大2.4MPa、 最少0.2Mpaと12倍程の違いがあり、非常に大きなばらつきがある。

破壊位置については、もっとも多かったのが塗床材と下地コンク リートとの界面であった。その部分を顕微鏡で観察すると、緑色の 塗床材が薄く付着している部分と全く付着していない部分とがある。 前者は、セメントペーストあるいは骨材部分であり、後者は表面が なめらかで光沢があり、下地が研磨されずにレイタンスが残留して いた部分である。また部分的にレイタンス部を破壊した領域もあり、 その場合は灰色の下地部分の破損として観察された。

またそれ程多くはなかったが塗床層自体での凝集破壊も見られた。 （2）レイタンスの残留比率と接着力との関倸

接着力にはレイタンス部分の存在が大きな影響を与えているよう であり、水セメント比 $60 \%$ のレイタンス部分の面積と接着力との 関倸を調べ図 12 に示す。レイタンス部面積は、目視で $10 \%$ 程度 で大きく区分わけをし、整理してある。レイタンス部分が多くなる と明らかに接着力が減少しており、塗床材塗布前のレイタンスの残 留は接着力に悪影響を及ぼしていると思われる。

\section{（3）下地湿潤の影響}

接着力に及ぼす水分の影響は顕著であり、すべての試験体で接着 力はおおよそ半分位まで低下している。すなわち塗床材裹面の水分 は接着力低下の大きな要因であると考えられる。また気乾状態では、 下地部分での破壊例もかなり存在していたが、湿潤状態では塗床材 と下地との界面での破壊がほとんどとなっている。

（4）下地コンクリートの水セメント比の影響

水セメント比別の接着力の影響を図 13 に示寸が、接着力に及ぼ す下地コンクリートの水セメント比の影響はほとんど見られなかっ た。これには、破損䇢所は塗床材と下地の界面が多く、また下地で 破損した場合でもレイタンス部分であり、結果として下地コンクリ 一トの本体部分の性質が、直接、接着力に反映しなかったためと思 われる。

\section{4 結論}

ここでは、下地のコンクリート自身及びその表面の性質がふくれ 発生に及ぼす影響について検討した。得られた本研究の結論は以下 のとおりである。

（1）塗床のふくれは、下地コンクリートの水セメント比の影響を 受け、水セメント比が高くなるほど発生しやすくなる。

（2）またこの時、ふくれ内部の圧力も高まっているが、これも下 地コンクリートの水セメント比の影響を受汁、水セメント比が高い 場合に、压力発生までの時間も早く、またここまでの測定では、最 大压力も高い。

（3）これにはコンクリートの半透過的性質に起因するふくれ溶液 側への水分移動が強く関与していると思われる。
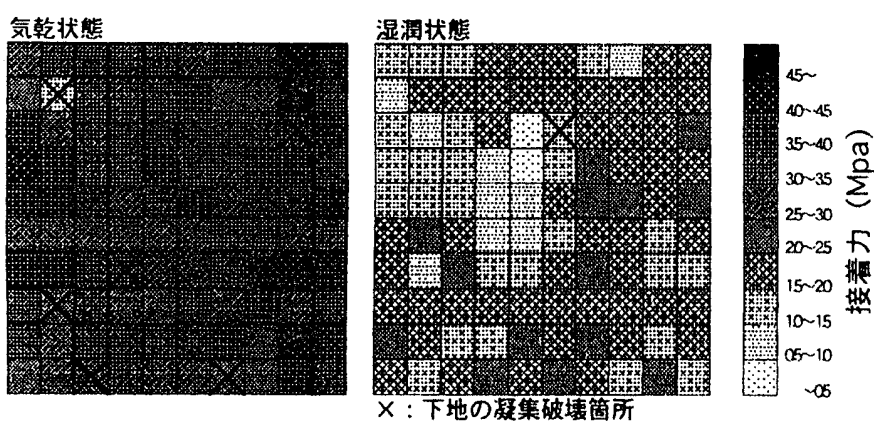

図-11 小面積接着力分布（W／C $60 \%$ ）

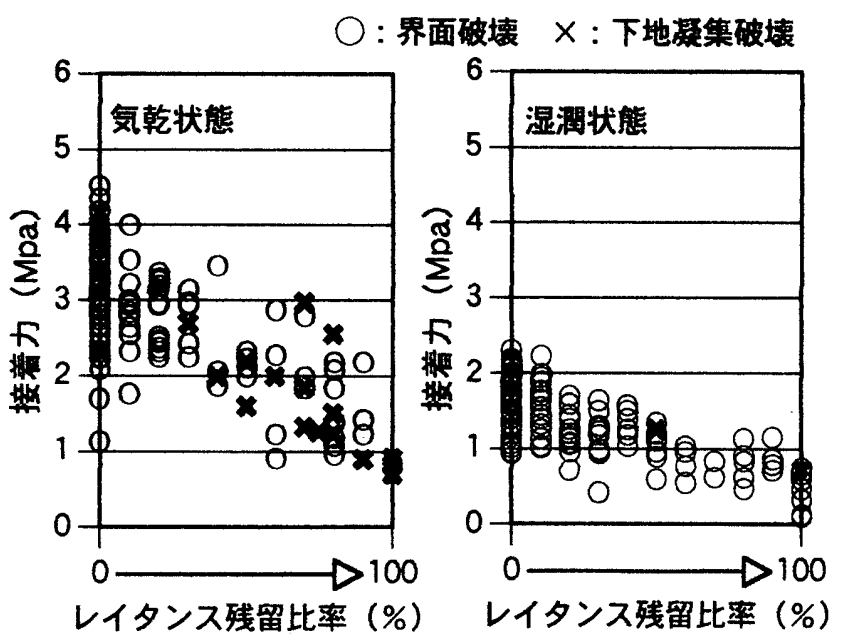

図-12 レイタンス部分の面積と接着力 (W/C60\%) （試験体 2 体の合計）

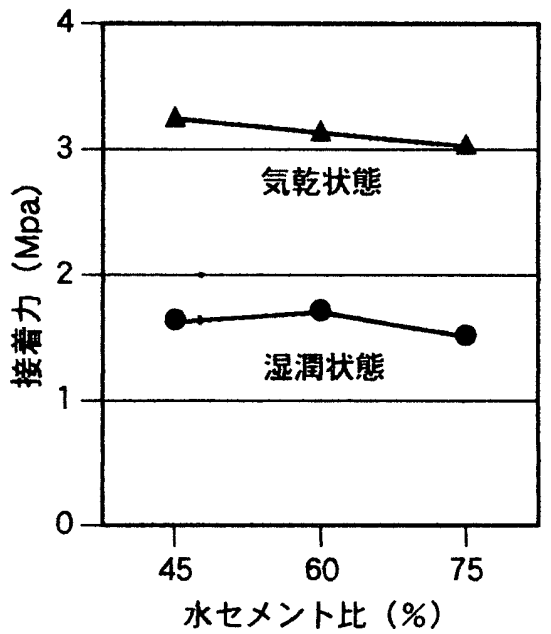

図-13 水セメント比別接着力 
（4）塗床材と下地との接着力は、数倍から十倍程度にばらついて 分布しており、特にレイタンス部分の接着力が低いこと、また湿潤 状態では著しく接着力の減少することが明らかになった。

\section{謝辞}

本研究を行うにあたり、（株）エービーシー商会前研究所長、浅 見 魅氏には大変お世話になりました。また清水建設（株）技術研 究所、橋田 浩氏、日本大学生産工学部建築工学科、湯浅 昇氏か らは、研究上の貴重な討論をいただきました。ここに謝意を表しま す。

\section{参考文献}

1) 田中享二、内田昌宏、大森 修、橋田 浩、湯浅 昇：塗り床 のふくれ発生機構の一考察; 日本建築学会構造系論文報告集、第 48 8号、揭載予定

2) W. J. Warlow and P.W.Pye:0smosis as a cause of blistering of in situ resin flooring on wet concrete; Magazine of
- concrete research, Vol. 130, No. 104, pp. 152-156, 1978

3) M. Gunter and H.K.Hilsdorf: Influence of physical and chemical interactions between concrete substrate and organic surface coatings on bond strength; Durability of

non-metallic inorganic building materials, pp. 161-174, 1988 4) 中井唯喜、村上信直、平野竜行：塗り床仕上げの標準化に関す る研究（その 2 ）故障要因に関する一考察; 日本建築学会大会学術 講演梗概集（A）、pp. 103-104, 1988

5 ）喜田大三、住田正博：若材令末乾燥コンクリート面の仕上げ工 法の研究（その1）；日本建築学会大会学術講演梗概集（A）、pp. 175-176, 1985

6 ）逸見義男、湯浅 昇、佐藤弘和、松井 勇、笠井芳夫：下地コ ンクリートの含水状態及び細孔構造がエポキシ樹脂系塗り床の接着 性に及ぼす影響：日本建築学会大会学術講演梗概集（A）、pp. 140 1-1402, 1995

7 ）守屋正祐、川地 武：コンクリート面塗膜の試験方法の提案； 日本建築学会大会学術講演梗概集（A）、pp. 1401-1402，1995 